\title{
Internalization and Actualization of Nationalism Values in Trijaya Tegal College Beliefs
}

\author{
Miftahul Janah ${ }^{1}$, Itmam Aulia Rakhman ${ }^{2}$ \\ Institut Agama Islam Bakti Negara (IBN) Tegal, kampus@ibntegal.ac.id ${ }^{1,2}$ \\ \{miftahuljinan@gmail.com¹,itmam.aulia@yahoo.com²\}
}

\begin{abstract}
This paper examines how to internalize and actualize the understanding of Nationalism in Trijaya's belief. This is important considering that in Tegal Regency itself, there are many different religions and spiritual beliefs for its people. In the Trijaya College itself, the students (putera) comes from various streams, beliefs and religions. In addition, Perguruan Trijaya which has been established for the past fifty-four years, it is able to live side by side in peace by still performing all its worship rituals with service. This research is a type of qualitative-descriptive research that uses methods etnografi-basis Native Point of View, to get the perspective of the owner of the culture as it is. The results showed that the internalization process went through two stages, internal refers to the introduction (pengantar) Romo Guru and externally through awareness of the history of the nation. Meanwhile, the actualization of the value of nationalism is manifested in the thanksgiving on national days and when the "putera" have separate events or events. Thanksgiving is marked with tumpengan and ampengan which have their respective philosophical values. In addition, they are willing to sacrifice and love the country and accept diversity as the actualization of nationalism.
\end{abstract}

Keywords: Actualization, Nationalism, Religion, Trijaya.

\section{Introduction}

The study of nationalism and the nation, as well as the nation-state, is still being debated by experts. For a number of circles, nation and national consciousness are believed to represent past states involved in efforts through a long historical process of self-realization. Nation in this meaning is a primordial entity in the form of innate inherent in human nature and history as a community. Objectively, a nation can be identified through its differences with other nations in terms of perspectives, ties to the homeland, and efforts to improve political autonomy. Some experts think that nationalism gained the momentum to develop rapidly along with the spread of the idea of democracy, the idea of people's sovereignty. It is very difficult to formulate definite definitions of nationalism and the nation-state. But if you pay attention to the seedbed arena of the initial conception of nationalism and the nation-state and also the logic behind the presence of nationalism and the nation-state that has grown in the former colony countries, it will be found that both are essentially treaty pacts between sovereign citizens and the state [1]. Anderson's thesis about "nations as imagined 
communities" is quite influential for the reformulation of current nationalism. He does not only discuss the issue of nationality in the context of the formation of the nation-state, but further exposes the ideology that is shrouded in national identity and national understanding $[2]$.

A profound feeling of a close bond with his homeland, with local traditions and the official rulers of the region has always existed throughout history with differing powers. Nationalism in the modern sense of the word becomes a feeling that is generally recognized. And this nationalism has an increasingly stronger role in shaping all aspects of life, creating and maintaining the sovereignty of a country, its own state, and that this state must encompass all nations. The bonds of nationalism grew in society when their mindset began to decline. This bond occurs when humans begin to live together in a certain area and do not move from there. At that time, their self-defense instinct played a big role and helped them to defend his country, where he lives and depend on himself. From here the seeds for the growth of these bonds, which are weak and of low quality. Nationalism in the dimensions of historicity and normativity is the most amazing social discovery in the course of human history, at least in the last decade. Nationalism becomes the socio-cultural umbrella of any country to strengthen its integrity. Nationalism is a socio-cultural "spirit" to form and strengthen national identity as a national identity that has the dignity of independence [3].

As a dialectical process, dynamic Indonesian Nationalism has grown and developed since the 20th century from cultural nationalism which was later transformed into political nationalism in the form of a nation-state through Pancasila and UUD 1945. Although, as believed by some circles, the structure of the Indonesian nation-state has not been shaken up to now, in the sense of nationalism it is still "alive", but lately its substance in democratic practices and the consequent application of law in the life of society and the state has begun to lose its direction. The condition of nationalism is a condition of a weakening of the attitude of nationalism, apart from the factor of weakening the commitment of citizens to Negara Kesatuan Republik Indonesia (NKRI), also due to the effects of global economic domination and regional decentralization [4]. All Founding fathers of the Indonesian nation carry the spirit of nationalism. However, nationalism in Indonesia has not yet fully materialized at the grassroots level. Nationalism in this country has not reached the point where the Indonesian nation has become a great and advanced nation in every aspect of life. In fact, the potential that this nation has, from Sumber Daya Manusia (SDM) and above all Sumber Daya Alam (SDA) which is very adequate to be able to lead the Indonesian nation to become a developed nation. Apart from the aforementioned, the Indonesian nation must have an adequate provision of mental and spiritual awareness, namely the awareness of nationalism on the basis of national brotherhood, justice and love for the country. Nationalism is actually always in line with all religions and beliefs in Indonesia [5].

The richness of the various spiritual cultures of various religions embraced by Indonesian citizens as well as the belief in the existence of the One True God that is lived by society for generations - called aliran kepercayaan- contributed to coloring the diversity of spiritual treasures in the archipelago. Indonesian people have always been accustomed to living in a nature that has various beliefs. Since the beginning of the development of its civilization, there has been a growing belief in God, successively religions that have now been recognized and validated by all elements of the Indonesian nation. The arrival of this religion does not mean that pre-existing idolatry and religions are gone, but that it continues to live and develop. All religions and beliefs teach kindness so that they respect and love each other. Religious norms teach humans to do good to others. Because humans are creatures of God who have the same dignity and character and have a noble mind and mind. In fact, the threat to national security 
and resilience is latent and can appear suddenly, because efforts to build national stability and resilience are increasingly with efforts to build nationalism awareness so as to form collective awareness of all elements of the nation and state of Indonesia to maintain the integrity of the nation [6].

Tegal Regency as an area that also has a variety of religions and spiritual cultures for its people, is interesting to explore from the content of nationalism and tolerance. The majority of the population of Tegal Regency in 2012 was Muslim, namely 1,579,393 people (99.47\%). The remaining 4,573 people $(0.29 \%)$ were Christians, 2,546 people $(0.16 \%)$ were Catholics, 512 people $(0.03 \%)$ were Hindus, 467 people $(0.03 \%)$ were Buddhist and 179 people $(0$, $01 \%$ ) are Confucian and 73 people have other religions. Coexistence and mutual tolerance between religions is well maintained. The infrastructure and facilities of worship for each religious adherent are also available and fulfilled in sufficient numbers. In 2013 there were 958 mosques and 3,384 prayer rooms / prayer rooms as places of worship for Muslims, 9 Christian churches where Christians are worshiped, 10 Catholic churches / chapels for Catholics, 1 temple / temple / Sanggah for Hindus, and 3 Vihara / Cetya / Klenteng, a place of worship for Buddhists / Confucians [7].

As for the updated data from Badan Kesatuan Bangsa dan Politik (Kesbangpol) Jawa Tengah, several religious belief organizations in Tegal Regency, including; Trijaya College has 3,000 members, 600 Instinct Javanese College, 196 Pangestu people, 1,564 Sri Murni people, 138 Persada members, and 257 Yoga Swastika members. Thus, the total number of followers of the belief in Tegal Regency is 6,780 people [8]. Trijaya College as a religious teaching school with the most number of members compared to others in Tegal Regency, has a secretariat on Jl. Layang No. 9 Tegalsari, City of Tegal and concentrating its activities at Padepokan Wulan Tumanggal in Dukuh Tengah Village, Bojong District, Tegal Regency. This college has been established since fifty-four years ago, it is able to exist and live side by side in peace while still carrying out all its rituals of worship solemnly.

Trijaya College in every activity agenda, always inserts national days as one of the major activities to be celebrated. In every activity, Romo Guru always give talks commonly referred to as "pengantar" as a medium for knowledge transfer for members of the Trijaya College which was later referred to as "Putera"- at the same time instilling awareness of the nation and efforts to understand diversity in the context of coexistence among people, members of society, and various groups that are manifested in this country. This paper examines how the Trijaya Tegal College understands and lives the teachings of nationalism as a manifestation of a belief which is then actualized in everyday life for each "son" of the Trijaya Tegal College. This research is a qualitative-descriptive type of research that uses a specific method in the form of ethnography-based Native Point of View, to obtain a "cultural owner" perspective.

\section{Research methods}

This research is qualitative in nature and uses ethnographic methods. The use of ethnographic methods shows the forms and patterns of activities, beliefs, language, and rituals. On the other hand, ethnography aims to produce an understanding as it is and is whole based on the perspective of the population or object under study.[9] Therefore, in this study, the emic of ethics is the point of view used in seeing cultural phenomena. Using emic or native point of view will certainly result in a natural and objective understanding. In this research, it means how nationalism is understood and lived by Trijaya universities, then actualized by them in their daily life either in their community or the general public. In ethnographic 
research, data collection uses observation and interview techniques. This needs to be done because it requires intensive involvement with the object under study, so that they can see their daily lives, habits and conversations.[10]

\section{Results and Discussions}

\subsection{Trijaya College: From Art to Spirituality}

The Indonesian nation has a diverse cultural wealth. One of the cultural properties is spiritual culture which is rooted in the belief in God Almighty. This spiritual culture is lived by some Indonesian people from generation to generation to the present. The spiritual community, known as the Believers of Belief in God Almighty, is in an organization (among others, called Paguyuban, Aliran and Perguruan), which up to now has recorded 249 organizations at the Central level and 980 organizations at the Branch Level. One of the organizations of Believers in the Belief in God Almighty is named "Perguruan Trijaya" was recorded on Direktorat Pembinaan Penghayat Kepercayaan terhadap Tuhan yang Maha Esa, Ditjenbud with an inventory number: 1.102/F.6/F.2/1980. Trijaya College was founded by RG. KP. Esno Kusnodho Suryaningrat on February 2, 1966, in the City of Tegal, Central Java. The Trijaya College Secretariat named Padepokan Argasonya is located at J1. Layang No.9 Rt.08 / 09, Tegalsari, Tegal, Central Java. As for the implementation of the deepening and appreciation of residents or members, it is carried out at Padepokan Wulan Tumanggal in Dukuh Tengah Village, Bojong District, Tegal Regency, on the northern slope of Mount Slamet [11].

In 1958-1962 Father Guru Esno Kusnodho studied with a man named Mbah Talang in Talang village, Talang District, Tegal Regency, Central Java. In 1964 by mbah Talang, Father Guru Esno was given the task and blessing to continue his studies at grandfather Bandung, in Bandung, West Java. After finishing, he developed his "knowledge" in the South Pemalang area. On Thursday Kliwon, January 13, 1966, with assistance Mbah Talang, Mr. Esno carrying out Arkat for the first time, which was continued with the stance Persatuan Pencak Silat Nasional (PPSN) on February 2, 1966 the Talang branch in Karangsari Village, Pulosari District, Pemalang Regency, Central Java. At first there were only a few members of the Trijaya College, but from time to time the number of members was increasing, especially after being officially registered with the directorate of Fostering Believers in God Almighty [12].

On progress, Perguruan Pencak Silat Nasional later changed to the martial art of Trijaya College, and the date of the founding of PPSN is still used as the day of the founding of the Trijaya College. The Putera (the term pupil in Trijaya) who helped develop Trijaya College and carried out the first arkat were: Putera Koesmoro, Putera Marto Sugondo, Putera Sendi, Putera Suwitno, Putera Gemuh and Putera D Raswad. The sons were then appointed as the Eldest Son of Trijaya College [13]. The Meaning of "Perguruan" is one of the vehicles or places to educate the person as a whole in studying, living, and deepening the culture of the Martial Arts through sports, feeling, and mental exercise. Meanwhile, Meaning "Trijaya" is a unit that contains three elements of strength that cannot be separated by studying, living and practicing by: (1). Studying exercise, taste, and mental exercise; (2). Serve God, Parents and Teachers; (3). Obey God's law, State law, and customary law. Until now, the Trijaya College continues to show its existence steadily, as the Trijaya College motto is "Life Is Devotion" [14]. 
The Martial Arts in Trijaya College is a human effort in defending himself both physically and spiritually in order to achieve the goal of life towards safety in the world and in the realm of eternity later. According to Trijaya's teachings, martial arts are divided into three, namely; First, physical self-defense, namely self-defense that is physical. This outer self-defense is intended as an effort to protect oneself against physical attacks from outside and can be used as a sport to keep the body healthy. Second, inner self-defense, which is self-defense that has inner strength with the intention of avoiding external attacks caused by subtle-forces created by humans or originating from evil spirits. And third, mental-spiritual self-defense, namely self-defense that is spiritual in nature with the intention of guarding oneself from behavior that is detrimental to oneself and others. This mental-spiritual self-defense has an aspect of life that leads humans to approach themselves to God Almighty. The basis for the implementation of the Trijaya College belief / science through the deepening of the Martial Arts is the steps 1 to 11 (eleven moves). Trijaya College which is supervised by RG. KP. Esno Kusnodho Suryaningrat is a vehicle for educating themselves (the sons) through learning, living and deepening martial arts in order to increase devotion through self-appreciation of the universe and God Almighty. Guided by the principles of its teachings, it is hoped that Trijaya College can produce individuals who are able to find their full identity, namely realizing who they are, for what their existence is in this life, as well as where the direction and purpose are after the end of the journey of life, in short, a person who knows and understand "Sangkan Paraning dumadi" so that in his life always: Eling, sumarah lan sumendhe marang kersaning Gusti", which means, Remember, surrender to the will of the Almighty God" [11].

\subsection{Internalization of Nationalism Values}

Several categories of nationalism, among others; (1) Citizenship Nationalism, a type of nationalism in which the state obtains political truth from the active participation of its people. (2) Ethnic nationalism, a type of nationalism in which the state obtains political and cultural truth of the origin or ethnicity of a society, (3) Romantic nationalism, is a continuation of ethnic nationalism in which the state obtains political correctness from the first to become "organic", the result of the nation or race. according to the spirit of romance. (4) Cultural nationalism, a type of nationalism in which the state obtains political correctness from a shared culture and not hereditary traits such as race color and so on, (5) Nationalism nationalism, variations of nationalism nationalism are always combined with ethnic nationalism, nationalistic feelings are strong so that they are given more priority overcoming universal rights and freedoms, and (6) religious nationalism, a type of nationalism in which the state derives political legitimacy from religious equality. Several categories of nationalism above are a reflection that the spirit of nationalism can grow and be applied in various fields of life, all components of society are responsible for participating in advancing the nation and state. Increasing nationalism is one way that can be done and provides an example for others [15].

The concept of internalizing the values of nationalism which is carried out at the Trijaya Tegal College is formulated into two things, the first is the internalization of internal factors, and second, the internalization that is motivated by external factors. As for what is meant by internal factors is to include the values of nationalism in every activity through descriptions which are termed by students as pengantar- Romo Guru which always emphasizes on national and land guidelines, namely the interpretation of the noble values of Pancasila through their please and Undang-undang Dasar (UUD) 1945. The "Pengantar" method that was delivered by Romo Guru at the beginning of each activity was felt to be accepted by the sons of Trijaya 
College so that the sons and daughters could become good citizens and could contribute in advancing their nation in the future. While external factors can the writer draw a common thread in the realization of awareness of the nation's history that grows and develops in each individual of the Trijaya Tegal College's Son.

\section{a) Introduction (Pengantar Romo Guru)}

Internalization of the teachings of nationalism taught in Trijaya college, originating and originating from the doctrine - in the term of the Trijaya College it is called the Pengantar- of Romo guru KRA Suryaningrat II. Use of terms pengantar is interpreted as a start that must be followed up further by the sons, namely by being lived and then carried out.[16] The philosophical meaning is that sometimes the doctrines and utterances of religious leaders or scholars are only limited to words that stop suddenly, cannot be actualized and implemented in real life. Of course, the degree to which a person follows the words of religious figures or leaders varies and it all depends on how one sees the figure of that leader. This then made the "pengantar" of Romo Guru well understood by the students (putera).

The introduction given by Father Guru contains teachings of nationalism. Nationalism itself is simply understood as loving the Indonesian nation [16]. Loving the Indonesian nation means having a sense of belonging and being responsible with everything the Indonesian nation has, be it the diversity and diversity of ethnicities, languages and religions, the unified state principle, namely Pancasila and so on. Nationalism is not much different according to Sartono Kartodirjo, which contains unity, liberty, equality and democracy [17]. Thus, nationalism is not far from the meaning of togetherness as a nation, because it has the same goals, interests, feelings and responsibilities to face the future, the past, common views, hopes in formulating the future ideals of the nation.

The introductions given by Romo Guru focused on Pancasila, Indonesia as a country that has laws that must be followed by every citizen, respecting each other by upholding human rights in a way that our rights also destroy and take away the rights of others, respect services of the heroes, maintaining customs and prioritizing public interests rather than personal interests. These introductions are conveyed in every event organized by Trijaya College, either on a national or regional scale or on a national or individual basis.

\section{b) Awareness of National History}

In an increasingly complex and dynamic social life, changes in the values of life often occur. This will always have an impact on the problem of changing new orders in the life of the nation and state from various aspects, including social, economic, educational, legal, cultural, political, and so on [18]. A nation as a community like individuals has parts and small units of personality which become a character, character and identity. The national personality generally stems from the common experience of a nation in its own history. When a person's identity and character are returned to his or her life history, the identity of a nation is referred to the historical roots of the nation itself. National history has a fundamental role in creating national awareness and national solidarity that comes from individuals who indirectly play an active role as well [19].

History is a bridge connecting the past and the present, and as a guide to the future. Apart from that, history is a reconstruction of the past, while something that is reconstructed is whatever has been thought, said, done, felt, and experienced by humans. The history of a nation includes its multiethnic development, its customary law system, language, kinship 
systems, beliefs, and so on [20]. Therefore, there needs to be an awareness of the history of the Indonesian nation which can be done formally or informally.

By having awareness of the history of the nation, it will gradually shape the character of nationalism. One of the manifestations is the awareness that the formation and independence of this nation is fought for and pursued by various groups and groups regardless of ethnicity and religion. Therefore, for Indonesians today, it is inappropriate to claim that only certain groups deserve to be heroes. This spirit was instilled in the sons of Trijaya College with the spirit of nationalism [16]. In another dimension, the sons of Trijaya College are also instilled with respect and are obliged to care for local cultural values (Javanese) as legacy from the nation's founders. Local cultural values are quite relevant to be revitalized in facing various conflict crises with social, economic, cultural, political dimensions, and including human rights issues that occur in the country. Historically, past experiences have often become so valuable in maintaining the existence of people's lives. The discourse is about efforts to revitalize the values of local wisdom as a step to empower local culture in anticipating the development of the era towards a better direction. This means that on the one hand there needs to be an effort to restore and revive the collective memory and awareness of local communities with their respective cultural characteristics and identities, while on the other hand there needs to be a commitment to increase collective collective awareness so that the growing awareness of national identity that already exists is in line with the historical development of this nation [21].

\subsection{Actualization of Nationalism Values}

Based on the history of its birth, nationalism or nationalism in the past was a middle way between two extremes, namely the darkness of imperialism or colonialism with the ignorance of ethnocentrism. Along with the development and changes in world life, nationalism is still relevant and returns as a middle way between the drums of globalization and the rise of ethnocentrism in the world community. The shift in the basic order of life has caused many things in the past nationalism to become obsolete and less meaningful in the present. For example, the slogan "live or die", "right or wrong is my country" sounds not only foreign but also naive, because nowadays awareness of legal equality and respect for human rights are essential, beyond a sense of nationality which is not the place. Fostering and awareness of the meaning of nationality no longer rely solely on sloganistic trends which to a certain extent will only foster romanticism that has sunk in the past and obscures the substance of true nationalism. Even so, slogans and symbols are still needed in fostering national identity, as long as these slogans and symbols are relatively honest and proportional.[22]

Nationalism as an ideology, requires actualization according to changing times and the challenges faced. The enemy of nationalism is no longer limited to imperialism, colonialism, separatism or other ideologies, but extends to things beyond that, such as poverty, underdevelopment, suppression of human rights and so on. This refers to the basic essence of nationalism which prioritizes common interests over personal and group interests, which implies a comprehensive justice, which all members of the nation must be able to feel. Poverty, underdevelopment and oppression indicate inequality and inequality in a nation's society, which means they are contrary to the basic essence of nationalism.[22]

The actualization of nationalistic values at the Trijaya Tegal College is shown through several things, among others; Thanksgiving celebrating national days and celebrating every historic moment. Willing to sacrifice and love the country is also one of the manifestations of the sustainable values of nationalism carried out by the sons. Another thing that is an 
indication of the actualization of the values of nationalism is the attitude of the sons who accept plurality.

\section{a) Thanksgiving : Celebration of National Days}

Each country has its own thanksgiving activities, including in Indonesia. Even though it is not officially celebrated by the government, being grateful by holding thanksgiving activities is mostly done by the Indonesian people, from farmers, fishermen, traders, to families, often performing thanksgiving rituals or it can be called salvation, as practiced by the Javanese and Sundanese. Thanksgiving is a form of thanksgiving event by inviting some relatives or neighbors. Traditionally, the thanksgiving event begins with prayer together, by sitting crosslegged on a mat circling rice cone with various side dishes according to the prevailing customs. Thanksgiving celebrations can also be found when the baby is present, of course the husband and wife feel happy with the gift of their child given by God. Usually they celebrate three months, four months and seven months (mitoni). Usually the event is filled with useful activities such as recitation, prayer and sharing. Almost all of God's gifts are celebrated by the people of Indonesia as a form of gratitude to Him. Thanksgiving for having a new home, thanksgiving for school graduation, thanksgiving for work, thanksgiving for promotion, thanksgiving for the inauguration of a new office, and other thanksgiving. Each region has a different tradition of thanksgiving, but the essence of all of this is for one purpose, namely to give thanks to God Almighty [23].

If nationalism is loving the Indonesian nation, and loving the Indonesian nation means feeling ownership and responsibility, then in the context of Trijaya College it is actualized in the form of Thanksgiving (Syukuran). This term is taken from the Arabic word Syakara which means to open, reveal, reveal, and show [24]. According to ar-Raghib al-Ashfahani that the word syukr also means as an effort to want to reveal God's blessings to the surface. [25] In Indonesian, Syukuran is defined as thanksgiving or holding salvation to give thanks to God, because it is avoided from death, recovered from illness, and so on. Thanksgiving (Syukuran) in the second meaning that is often done by Trijaya College in sacred moments of the nation. Like commemorating Pancasila Day, Independence Day or Kartini Day. On the other hand, thanksgiving is also always carried out by higher education sympathizers after they are declared successful and declared as sons (Putera), so the Putera hold a thanksgiving (khataman), as a token of gratitude to God Almighty, that the Putera has knowledge of His grace through the guidance of Romo Guru [13].

Apart from thanksgiving in sacred moments of national day, thanksgiving is also done when the sons have a private celebration or event, such as a birthday. The difference in gratitude in the two moments is the model and form of the food served. If during the national moment it is called tumpengan, which is cone-shaped rice, while during personal celebration it is called ampengan, which is flat rice [16]. There is meaning behind the form of thanksgiving rice in both moments. Tumpengan means upholding national values or respect for heroes, apart from being a form of hope that the Indonesian nation will become a prosperous and peaceful nation. While Ampengan, means that humans have the same degree of mutual respect and help each other [16].

Tumpeng is a traditional Indonesian food that is widely used during ceremonies and activities such as celebrations, inauguration of weddings, and thanksgiving. The food is served in the form of rice in a cone shape, arranged on a banana leaf with a variety of side dishes. The tradition of using tumpeng rice as a requirement in ceremonies related to the life cycle, celebrating celebrations, and expressions of petition is still very strong in Javanese society, 
especially in the areas of Central Java and Yogyakarta. The tradition of tumpengan is routinely carried out both among the community and government circles which are religious or cultural. Tumpeng culture has existed in Indonesia since the days of the kingdom. It is written in centhini fiber in 1814. The following is an excerpt of centhini fiber content which mentions the tradition of tumpengan; "Tumpeng megana neng tengah (Tumpeng rice is in the middle), Pisang kepel balimbing nganan mengeling (Banana peel, starfruit, surround), Kinubeng rampadanipun (Filled with a variety of foliage), Ulam mawarna-warna (Various kinds of fish), Brambang bawang timun sumerit kinecut (Shallots, garlic and cucumber complete), Lalapan kemangi cambah (Lalapan basil leaves, sprouts), Sambal ulek pecel Pitik (Sambal ulek pecel ayam)." The use of tumpeng as a symbol for requests can be divided into four aspects, namely; Use in the circle of life, offerings for safety in the environment of relatives and the Yogyakarta Palace, various family needs, and various community activities. The variety of events and ceremonies that use tumpeng rice as a condition causes various types of tumpeng rice according to their intended use [26].

\section{b) Willing to Sacrifice and Love the Country (Cinta Tanah Air)}

In the opening Undang-undang Dasar 1945, The government has a central role to play in enhancing the spirit of nationalism to promote public welfare, enlighten the lives of nations, and participate in world order based on independence, lasting peace, and social justice. The spirit of nationalism is also present in Pancasila in the third precept, namely, the Indonesian Association, which has characteristics such as loving the nation and homeland of Indonesia, willing to sacrifice for the nation and country, proud of the nation and the homeland of Indonesia, and put the interests of the nation and country above personal or group interests [15].

In the lyrics Mars Anak Alam Nusantara (AAN) There is also an expression to motivate the sons to build together the Indonesian nation. The lyric snippet reads "Ayo semua, Tua muda, Pria wanita, Bersama saya, Membangun nusa bangsa". A hope that the recognition and behavior of this nation must and must be beautifully engraved in all the vibrations of his life, that is the wish of the composer of this song. In less than 10 minutes this song was composed by the supervisor of Trijaya Padepokan Argasonya Pusat Tegal, RG. KPA. Esno Kusnodho Suryaningrat or who is familiarly called Father Guru Bapak Tegal, where the musical arrangement was worked on by Mas Herjuno in March 2011. The second stanza emphasizes the belief of a nation that is always united in defending the country like a solid rock that has the ability to withstand the magnitude of waves attack, chest the Garuda encrusted area as an insoluble fortress. At the end of the verse of Mars AAN, there is a hope for all the sons and daughters of the nation to build together the nation and the nation [11]. The teaching and invitation to build the nation must of course be implemented in the form of being willing to sacrifice in order to achieve the noble ideals of the nation.

The willingness to sacrifice was instilled from the earliest to the Princes of Trijaya Teaching by Romo Guru and also the Putera Sulung (The name for the first students of the Trustees and Founders of Trijaya College). Romo Guru train a self-sacrificing attitude with various thanksgiving activities held in mutual cooperation by giving contributions in the form of thoughts, energy, funds, and everything else to the success of an activity. Sacrificing for the benefit of others is also reflected in the construction of clean water reservoirs in the Padepokan Wulan Tumanggal location, Bojong District, and distributed to residents in the surrounding community, regardless of class, religion and other distinguishing factors. Padepokan Wulan Tumanggal also often initiates mutual fundraising for the construction or 
renovation of places of worship, such as mosques or prayer rooms around the hermitage [16]. Willing to sacrifice means being willing to give something as a statement of devotion or loyalty which is done with a sincere heart, a willingness to sacrifice is not only for the interests of the nation and the state, but an attitude of self-sacrifice can be done in various environments, namely the school family environment and the community or residence [27].

\section{c) Receive Diversity}

Indonesia is one of the most multicultural countries in the world. The structure of Indonesian society is characterized by two mainstream forms. Horizontally, it is characterized by the fact that there is social unity - social unity based on differences - ethnicity, religious differences, customs, and regional differences. Vertically, the structure of Indonesian society is marked by a sharp vertical difference between the upper and lower layers. This fact explains that in everyday life the picture of the differences that are being experienced in society is indeed a significant difference. Like it or not, the Indonesian people realize that in addition to this amount can be a potential and joint capital in building the nation's civilization, it also cannot be denied that the large population with all the diversity in it can be a barrier to the ideals of the nation's life.[28] Each ethnic group will produce culture and because the ethnic groups in Indonesia are diverse, it is very easy to find the diversity of Indonesian culture. The diversity found does not lie in the cultural element, but in the body of the culture, in other words that cultural elements such as arts, language, knowledge systems, social systems and organizations, livelihood systems, technology systems and equipment will be found. in every ethnic group. The reality about the plurality of Indonesian society is not only from the aspect of ethnicity and culture but also religion [29].

For a pluralistic society like in Indonesia, the effort to formulate an agreement for a value agreement is not as easy as turning your hand. Every society always has fundamental tendencies to maintain the uniqueness of their identity. The cause is none other than that the survival and existence of a society is largely determined by its ability to maintain its integrity and integrity. Efforts to maintain his integrity will be carried out naturally when he faces challenges or pressures for change that come from outside. As the concept of the Medina charter in the era of the Prophet Muhammad, so is Pancasila and the 1945 Constitution which are an agreement between groups to build a common political society [30]. In a dynamic social life, diversity is not a stagnant inanimate object. It is alive and dynamically following developments according to the context of the times. The reality of the diverse Indonesian nation cannot be denied that it has a strong potential for the emergence of various social problems with nuances of identity in the sphere of social life. The memory of the incidents of conflicts with ethnic, religious, racial and inter-group nuances that broke out and exploded in the early days of reform, such as those that occurred in Ambon, North Maluku, Poso, West Kalimantan, and Central Kalimantan. These social events are a series of areas of social conflict on a large scale that are filled with ethnic and religious differences [28].

Understanding the pluralistic reality should not be limited to the level of discourse, but must also be manifested in life, in tolerant attitudes and behavior. By understanding the meaning of plurality, it will provide a dynamic, harmonious and tolerant life order (Baharun, 2016). "External tolerance" in the form of mutual respect between adherents of religious communities will manifest together with the awareness of each religious adherent in addressing any differences that arise in the teachings of his religion. Difference is a necessity, even within one religion, from various lines, from the practice of worship, to different expressions and interpretations of a religious text, and so on. This attitude of mutual 
understanding and respect within a religious teaching community can also be called "internal tolerance." [31].

Trijaya Tegal College is attended by various groups of people and religions or beliefs. One of the requirements to become a son is a letter of consent from the parents or the sons' family. On the other hand, parents or families are allowed (even invited) to find out in detail the activities of the Trijaya College, so as not to cause suspicion for their families. Some of the sons I interviewed claimed to be Muslim, some were Christian, and some of them were followers of the belief in One God. The diversity of the sons of the Trijaya College will certainly have the potential to create friction between sons. However, as short as the writer finds it through in-depth interviews, it almost never happens. One of the things that triggers the growth of an attitude of mutual respect and being able to accept all differences is the advice in every introduction given by Romo Guru and the emphasis on the values of Pancasila and the 1945 Constitution as a reference in understanding diversity, both in the nation, in society, in the realm of practical politics, and of course also in terms of worship. The challenge of plurality in the Trijaya Higher Education forum was responded to very wisely. The theological solution initiated by its founder, among others, is in the form of active collective prayer in every moment which is a form of building togetherness which of course gradually diminishes the differences that previously manifested in each individual son of the College. The sons realize that social tension (conflict) should be put aside by efforts to control themselves and eliminate all potential conflicts so that they are still considered as the son of Trijaya College. This awareness is continuously built by each individual not only because of existence Anggaran Dasar/ Anggaran Rumah Tangga (AD/ART), but more on the goal of achieving a true life, which is to continue to serve, do good to others, and glorify God Almighty in every act and event.

According to experts, this pattern of awareness will bring oneself closer to the concept of spirituality, because spirituality emphasizes a person's attitude in understanding his life experiences. As Elkins et al. mentions spirituality comes from Latin which means breath of life. In its definition, spirituality is a way of being and experiencing which arises because of an awareness of the transcendent dimension and is characterized by certain values that appear good in oneself, others, nature, life, and whatever is considered. as "The Ultimate" (the Ultimate). Spirituality makes a person feel a strong desire and urge to understand various things in life, whether it is religious or other. In Javanese life, this spiritual awareness is closer to the value of personal kebatinan or better known as laku. Laku in Javanese is the same as action, which means move, action, obligation, and way. However, what is meant here is practice-action (Way of Life: way of life), in attaining nobility and perfection of life. The emphasis is more on the spiritual attitude of a person to get closer to God through the mind, otherwise known as ngelm [32]. As quoted from the book "Himpunan Pitutur Luhur" one of the references in his writing was Perguruan Trijaya Tegal, disclosed "Urip kang utama, mateni kang sampurna" which means that a person in the course of his life must always say and do good in accordance with the instinct, so that at the moment of death in a state of innocence. The meaning is manifested in the attitude and behavior of all thoughts, words, and deeds performed, always tried to be sourced from and sourced by the love of God Almighty. Such attitudes and behaviors are applied in one's relationship with oneself, others, and God Almighty [33].

\section{Conclusion}


Internalization is something that is subjective as a form of appreciation and inclusion of teaching values that each group or community will have different. Likewise with the actualization of the teachings and understandings given. In the Trijaya College Trust community, Pengantar Romo Guru has a significant role in shaping the understanding of nationalism towards students (Putera). Apart from being a position Romo Guru as figures and leaders in Trijaya College who have charisma, of course, do not forget continuity and continuity Pengantar Romo Guru which is always given in every event. Then, the awareness of the sons (Putera) of the nation's history forms a complete understanding of the meaning and purpose of nationalism. Meanwhile, the actualization of nationalism carried out by the sons of the Trijaya College is a sense of gratitude by holding thanksgiving in every sacred moments of the National holidays. Signed by tumpengan, not ampengan, with a tapered shape means upholding national values and as the hope of a prosperous and peaceful nation. In addition, actualization is manifested in an attitude of being willing to sacrifice and loving the country and accepting plurality.

\section{References}

[1] C. Lay, "Nasionalisme dan Negara Bangsa'," J. Ilmu Sos. dan Ilmu Polit., vol. 10, no. 2, pp. 165-180, 2006.

[2] C. Anwar, "Internalisasi Semangat Nasionalisme Melalui Pendekatan Habituasi (Perspektif Filsafat Pendidikan)," Anal. J. Stud. Keislaman2, vol. 14, no. 1, pp. 159172, 14AD.

[3] Aman, "Aktualisasi Nilai-nilai Kesadaran Sejarah dan Nasionalisme dalam Pembelajaran Sejarah di SMA,” J. Pendidik. Karakter2, vol. IV, no. 1, pp. 23-34, 14AD.

[4] M. A. M. Thung Ju Lan, Nasionalisme dan Ketahanan Budaya di Indonesia; Sebuah Tantangan. Jakarta: LIPI Press, 2011.

[5] A. A. Gunawan, Nasionalisme Religius Untuk Indonesia. Sukabumi: Sanggar Seni Budaya, 2019.

[6] S. Suharto, Kebijakan Pemerintah Sebagai Manifestasi Peningkatan Toleransi Umat Beragama Guna Mewujudkan Stabilitas Nasional dalam Rangka Ketahanan Nasional. Ponorogo: REATIV, 2019.

[7] P. K. Tegal, Sistem Informasi Profil Daerah (SIPD) Kabupaten Tegal Tahun 2016. Tegal: SIPD, 2017.

[8] Kesbangpol, "Data Organisasi Penghayat Kepercayaan Terhadap Tuhan Yang Maha Esa Se Jawa Tengah," 2016. [Online]. Available: https://kesbangpol.jatengprov.go.id/wp-content/uploads/2018/05/Data-OrganisasiPenghayat-Kepercayaan-Se-Jawa-Tengah-2017.pdf.

[9] J. P. Spradley, Metode Etnograf. Yogyakarta: PT. Tiara Wacana, 1997.

[10] E. Kuntjara, Penelitian Kebudayaan Sebuah Panduan Praktis. Yogyakarta: Graha Ilmu, 2006.

[11] P. Trijaya, "Perguruan Trijaya: Arti, Tujuan, dan Makna Lambang," 2016. [Online]. Available: http://www.perguruantrijaya.org/p/perguruan-trijaya-seni-bela-diri.html.

[12] P. I. K. T. T. Y. M. E. (Indonesia), Hasil Penelitian Organisasi Kepercayaan Terhadap Tuhan Yang Maha Esa Daerah Tingkat I Propinsi Jawa Tengah. Jakarta: Departemen Pendidikan dan Kebudayaan, Direktorat Jenderal Kebudayaan, Direktorat Pembinaan Penghayat Kepercayaan Terhadap Tuhan Yang Maha Esa, Proyek Inventarisasi 
Kepercayaan Terhadap Tuhan Yang Maha Esa, 1987.

[13] D. P. dan Kebudayaan, Ajaran Organisasi Penghayat Kepercayaan Terhadap Tuhan Yang Maha Esa [nama organisasi]: Tri Jaya. Jakarta: Departemen Pendidikan dan Kebudayaan, 1998.

[14] D. K. T. T. Y. M. E. Indonesia, Ensiklopedi Kepercayaan Terhadap Tuhan Yang Maha Esa. Jakarta: Direktorat Jenderal Nilai Budaya, Seni dan Film, Direktorat Kepercayaan Terhadap Tuhan Yang Maha Esa, 2006.

[15] N. Majid, Penguatan Karakter Melalui Local Wisdom sebagai Budaya Kewarganegaraan. Sulawesi Selatan: Yayasan Ahmar Cendekia Indonesia, 2019.

[16] S. F. (Bandung), "Wawancara Putera Padepokan Trijaya Tegal," Tegal, 2020.

[17] S. Kartodirjo, Multidimensi Pembangunan Bangsa Etos Nasionalisme dan Negara Kesatuan. Yogyakarta: Kanisius, 1999.

[18] I. A. Rakhman, "Islam dan Egalitarianisme: Ruang Terbuka Kesetaraan Gender," AtTa'wil, vol. 1, no. 01, pp. 62-73, 2019.

[19] S. Kartodirjo, Pendekatan Ilmu Sosial dalam Metodologi Sejarah. Jakarta: Gramedia Pustaka Utama, 1992.

[20] Kuntowijoyo, Metodologi Sejarah. Yogyakarta: Tiara Wacana, 1994.

[21] I. B. Brata, "Kearifan Budaya Lokal Perekat Identitas Bangsa," J. Bakti Sar., vol. 05, no. $01,2016$.

[22] A. Kusumawardani, "Nasionalisme," Bul. Psikol., vol. XII, no. 2, pp. 61-72, 2004.

[23] S. Risat, Jiwa Bahagia. Jakarta: TransMedia, 2015.

[24] I. Manzhur, Lisan al-Arabi. Bairut: Dar al-Fikr.

[25] A.-R. Al-Ashfahani, Mu'jam Mufrodat al-Fadhil al-Qur'an. Lebanon: Dar al-Kutub alIlmiyyah, 2008.

[26] E. M. Dukut, Kebudayaan, Ideologi, Revitalisasi dan Digitalisasi Seni Pertunjukan Jawa dalam Gawai. Semarang: SCU Knowledge Media, 2020.

[27] S. Kartini, Jiwa Patriotisme. Jakarta: Alprin, 2020.

[28] N. Mahyuddin, Muhammad Rusdi, Ilham, Masna, Nugrahayu, Nur Nadiya Rahma, A. Jurana Anggriana, Silmi Qurota Ayun, Fitriani, Agama dan Masyarakat Multikultural: Pilar-pilar Membangun Kebersamaan dalam Perbedaan. Parepare: IAIN Parepare Nusantara Press, 2020.

[29] Wahyuni, Agama dan Pembentukan Struktur Sosial: Pertautan Agama, Budaya, dan Tradisi Sosial. Jakarta: Kencana, 2018.

[30] D. Soegeng Hardiyanto, Martin Lukito SInaga, Darius Dubut, Agama dalam Dialog: Pencerahan, Pendamaian, dan Masa Depan. Jakarta: BPK Gunung Mulia, 2003.

[31] I. A. Rakhman and Z. Zakiyah, "Tradisi 'Lawean' Masyarakat Pesayangan (Studi Living Qur'an),” IBDA` J. Kaji. Islam dan Budaya, vol. 17, no. 2, pp. 302-318, Dec. 2019, doi: 10.24090/ibda.v17i2.2873.

[32] K. S. S. Nugroho, Laku \& Ngelmu Spiritual Jawa. Jakarta: Lakeisha, 2020.

[33] D. K. T. T. Y. M. E. Indonesia, Himpunan Pitutur Luhur. Jakarta: Direktorat Jenderal Nilai Budaya, Seni dan Film, Direktorat Kepercayaan Terhadap Tuhan Yang Maha Esa, 2007. 